Full-length article

\title{
Development of a universal high-throughput calcium assay for G-pro- tein-coupled receptors with promiscuous G-protein $\mathbf{G}_{\alpha 15 / 16^{1}}$
}

\author{
Ting ZHU ${ }^{2,4}$, Li-yan FANG ${ }^{2,3}$, Xin XIE ${ }^{2,3,5}$ \\ ${ }^{2}$ The National Center for Drug Screening, ${ }^{3}$ Shanghai Institute of Materia Medica, ${ }^{4}$ Shanghai Institutes for Biological Sciences, Chinese \\ Academy of Sciences, Shanghai 201203, China
}

\section{Key words}

G-protein-coupled receptors; G-protein; Ga15/16; high-throughput screening; calcium assay; GTP $\gamma \mathrm{S}$ binding

\footnotetext{
'Project supported by grants from the Chinese Academy of Sciences (No KSCX2-YW-R18), the Ministry of Science and Technology of China (No 2006AA020602), and the Shanghai Commission of Science and Technology (№ 05PJ14313, 06DZ22907). ${ }^{5}$ Correspondence to $\mathrm{Dr}$ Xin XIE. Phn 86-21-5080-1313, ext 156. Fax 86-21-5080-0721.

E-mail xxie@mail.shcnc.ac.cn
}

Received 2007-09-25

Accepted 2008-01-02

doi: $10.1111 / \mathrm{j} .1745-7254.2008 .00775 . \mathrm{x}$

\begin{abstract}
Aim: To develop a universal high-throughput screening assay based on Ga15/16mediated calcium mobilization for the identification of novel modulators of Gprotein-coupled receptors (GPCR). Methods: In the present study, CHO-K1 or HEK293 cells were co-transfected with plasmids encoding promiscuous G-protein

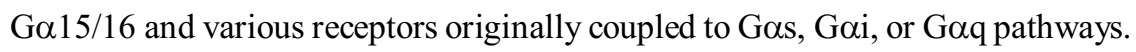
Intracellular calcium change was monitored with fluorescent dye Fluo-4. Results: We found out for all the receptors tested, Ga15/16 could shift the receptors' coupling to the calcium mobilization pathway, and the $\mathrm{EC}_{50}$ values of the ligands generated with this method were comparable with reported values that were obtained using traditional methods. This assay was validated and optimized with the $\delta$-opioid receptor, which originally coupled to Gai and was recently found to play important roles in neurodegenerative and autoimmune diseases. A largescale screening of 48000 compounds was performed based on this system. Several new modulators were identified and confirmed with the traditional GTP $\gamma \mathrm{S}$ binding assay. Conclusion: This cell-based calcium assay was proved to be robust and easy to automate, and could be used as a universal method in searching for GPCR modulators.
\end{abstract}

\section{Introduction}

G-protein-coupled receptors (GPCR) constitute one of the largest and most versatile families of cell surface receptors $^{[1]}$. GPCR recognize and respond to a variety of extracellular stimulants and endogenous ligands, including light, odors, taste substances, hormones, chemotactic factors, and neurotransmitters ${ }^{[2]}$. Due to the variety of physiological and pathological functions regulated by GPCR, they were considered the most promising drug targets in the pharmaceutical industry. It is estimated that over $50 \%$ of the marketed drugs are modulators of GPCR functions ${ }^{[3,4]}$. With the completion of the Human Genome Project, approximately 1000 genes encoding GPCR were identified, but only about 200 have known ligands and functions ${ }^{[5]}$. Searching for ligands of the orphan GPCR and better modulators of known receptors will provide new opportunities in future drug discovery.

GPCR are 7 transmembrane proteins with the amino ter- minal and carboxy terminal located in the extracellular and intracellular spaces, respectively ${ }^{[6]}$. After ligand stimulation, GPCR undergo conformational change and activate the intracellular G-proteins, which are composed of $\alpha, \beta$, and $\gamma$ subunits, and then initiate signaling to the cell interior ${ }^{[7]}$. Based upon the structure and downstream signaling cascade,

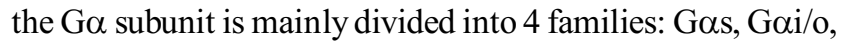

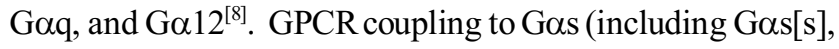
Gos[1], Gas[xl], Gos[xxl], and Goolf) activate adenylate cyclase, which catalyses cAMP production. Contrarily, Gai/o

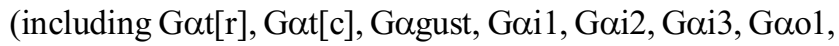

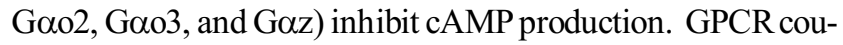

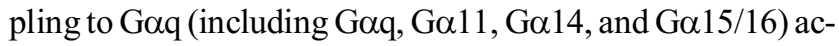
tivate phospholipase $C \beta$, which catalyzes the generation of $\mathrm{IP}_{3}$ and calcium release from intracellular store ${ }^{[9,10]}$. Ga12

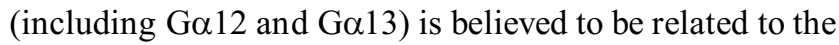
activation of Ras, Raf, and ERK pathway ${ }^{[11]}$. 
Based on the signal transduction cascade of GPCR, several assay techniques for GPCR ligand screening, such as radioligand binding, $\left[{ }^{35} \mathrm{~S}\right]-\mathrm{GTP} \gamma \mathrm{S}$ binding, reporter gene, cAMP detection, and calcium mobilization are commonly used. Radiometric techniques not only require an advanced laboratory, but also generate environment pollution and impair people's health. So non-radiometric assays, especially cell-based functional assays, played more important roles in primary screening ${ }^{[12]}$. However, these assays can only be applied for selected G $\alpha$ subtypes. For example, cAMP assay can only be used for Gas and Gai/o-coupled GPCR, and calcium mobilization only for Gaq-coupled receptors. These assays require well-characterized signaling pathway of the receptors, so they would be difficult to apply to orphan GPCR.

It is therefore apparent that a universal high-throughput screening (HTS) approach for GPCR ligand screening would be valuable. Previous studies have demonstrated that most receptors promiscuously couple to several Go subtypes, but because one of the G-proteins occupied the dominant status, it is hard to detect signals induced by other Go subtypes ${ }^{[13]}$. Overexpression of certain G $\alpha$ subunits can shift the original coupling pathway of GPCR to the new one $\mathrm{e}^{[13,14]}$. In the present paper, we tested the coupling of the promiscuous G-protein Ga15/16 (mouse/human orthologs, respectively ${ }^{[15]}$ ) with various receptors that originally coupled to the Gas, Gai, or Gaq pathways. We found out for all the receptors tested, Ga15/16 shifted the receptors coupling to the calcium mobilization pathway, and intracellular calcium change could be easily detected with a Fluo-4 fluorescent indicator. Ligand efficacy measured by this method was comparable with the value obtained using traditional methods. This assay was validated with the $\delta$-opioid receptor (DOR), which originally coupled to Gai and may play important roles in pain, neurodegenerative, and autoimmune diseases ${ }^{[16-18]}$. A large-scale screening of 48000 compounds was performed based on this system. Several new modulators (including both agonists and antagonists) were identified and confirmed with the traditional $\left[{ }^{35} \mathrm{~S}\right]-\mathrm{GTP} \gamma \mathrm{S}$ binding assay. This cell-based calcium assay was proved to be robust and easy to automate, and could be used as a universal method for the search of GPCR modulators.

\section{Materials and methods}

Reagents Mammalian expression vectors encoding cannabinoid receptors 1 and 2 (CB1 and CB2), $\alpha 1$ a adrenergic receptor ( $\alpha 1 \mathrm{aAR}), \alpha 2 \mathrm{~b}$ adrenergic receptor ( $\alpha 2 \mathrm{bAR})$, dopamine receptor 5 (DRD5), and Ga15/16 were purchased from UMR cDNA Resource Center (Rolla, MO, USA). Plasmids encoding chemokine receptors CCR5, CXCR4, $\delta$-opioid receptor, and $\beta 2$ adrenergic receptor ( $\beta 2 \mathrm{AR})$ were kindly provided by Dr Gang Pei from Shanghai Institutes for Biological Sciences (Shanghai, China). Fluo-4 AM was purchased from Invitrogen (Carlsbad, CA, USA). FlashBlue GPCR scintillation beads and $\left[{ }^{35} \mathrm{~S}\right]-\mathrm{GTP} \gamma \mathrm{S}$ were products of PerkinElmer (Boston, MA, USA). SDF-1 was purchased from GL Biochem (Shanghai, China). Sulfinpyrazone, RANTES, DPDPE, isoproterenol, phenylephrine, dopamine, noradrenalin, TIPP$\psi$, naltrindole, $\left[D\right.$-Ala $\left.{ }^{2}\right]$-deltorphin II and DADLE were purchased from Sigma-Aldrich (St Louis, MO, USA). Other reagents and solvents used in the experiments were of analytical grade.

Cell transfection CHO-K1 or HEK293 cells were obtained from ATCC (Manassas, VA, USA) and maintained in F12 nutritional medium or Dulbecco's modified Eagle's medium supplemented with $10 \%$ fetal bovine serum, $100 \mathrm{mg} / \mathrm{L}$ penicillin, and $100 \mathrm{mg} / \mathrm{L}$ streptomycin at $37^{\circ} \mathrm{C}$ in a humidified atmosphere of $5 \% \mathrm{CO}_{2}$. For transient transfection, approximately $1 \times 10^{6}$ cells were mixed with $2 \mu \mathrm{g}$ plasmids in $200 \mu \mathrm{L}$ transfection buffer, and electroporation was carried out with a Scientz-2C electroporation apparatus (Scientz Biotech, Ningbo, China). The experiments were carried out $24 \mathrm{~h}$ after transfection. For stable cell line generation, the transfected cells were seeded into $10 \mathrm{~cm}$ dishes, and proper antibiotics (500 $\mu \mathrm{g} / \mathrm{mL} \mathrm{G418}$ and/or $20 \mu \mathrm{g} / \mathrm{mL}$ blasticidin) were added to the culture medium the next day. The selection medium was changed every $3 \mathrm{~d}$ until colonies were formed. The single colony was picked up, expanded, and tested for the expression of transfected genes.

Calcium mobilization assay $\mathrm{CHO}$ cells co-transfected with receptors and Ga15/16 were plated onto 96-well plates at a density of 30000 cells $/ 100 \mu \mathrm{L}$ per well and incubated overnight. The cells were loaded with $2 \mu \mathrm{mol} / \mathrm{L}$ Fluo-4 AM in Hanks' balanced salt solution (HBSS; containing 5.4 $\mathrm{mmol} / \mathrm{L} \mathrm{KCl}, 0.3 \mathrm{mmol} / \mathrm{L} \mathrm{Na}_{2} \mathrm{HPO}_{4}, 0.4 \mathrm{mmol} / \mathrm{L} \mathrm{KH}_{2} \mathrm{PO}_{4}$, $4.2 \mathrm{mmol} / \mathrm{L} \mathrm{NaHCO}_{3}, 1.3 \mathrm{mmol} / \mathrm{L} \mathrm{CaCl}_{2}, 0.5 \mathrm{mmol} / \mathrm{L}$ $\mathrm{MgCl}_{2}, 0.6 \mathrm{mmol} / \mathrm{L} \mathrm{MgSO}_{4}, 137 \mathrm{mmol} / \mathrm{L} \mathrm{NaCl}, 5.6 \mathrm{mmol} / \mathrm{L}$ $D$-glucose, and $250 \mu \mathrm{mol} / \mathrm{L}$ sulfinpyrazone, $\mathrm{pH} 7.4$ ) at $37{ }^{\circ} \mathrm{C}$ for $50 \mathrm{~min}$. After removal of the excess dye, the cells were rinsed with HBSS once. In the antagonist mode, $50 \mu \mathrm{L}$ HBSS containing known antagonists (positive control), compounds of interest, or DMSO (negative control, final concentration 1\%) were added. After incubation at room temperature for $10 \mathrm{~min}, 25 \mu \mathrm{L}$ agonists were dispensed into the well with a FlexStation II micro-plate reader (Molecular Devices, Sunnyvale, CA, USA), and intracellular calcium change was recorded with an excitation wavelength of $485 \mathrm{~nm}$ and emission wavelength of $525 \mathrm{~nm}$. In the agonist mode, $50 \mu \mathrm{L}$ HBSS was added to the dye- 
loaded cells, and $25 \mu \mathrm{L}$ of known agonists (positive control), compounds of interest, or DMSO (negative control, final concentration $1 \%$ ) were added with FlexStation II, and calcium change was measured.

$\left.{ }^{[35} \mathbf{S}\right]-\mathbf{G T P} \gamma \mathbf{S}$ binding assay Cell membranes were isolated as previously described ${ }^{[19]}$. In brief, $\mathrm{CHO} / \mathrm{DOR}$ cells were pelleted by centrifugation and resuspended in lysis buffer $(5 \mathrm{mmol} / \mathrm{L}$ Tris-HCl, $5 \mathrm{mmol} / \mathrm{L}$ EDTA, and $5 \mathrm{mmol} / \mathrm{L}$ EGTA, pH 7.5), and then homogenized with a Dounce tissue grinder. The lysate was centrifuged at $1000 \times g$ for 10 min. After removal of the deposition, crude membranes were then pelleted by centrifugation at $12000 \times g$ for 15 min at $4{ }^{\circ} \mathrm{C}$. The membranes were resuspended in reaction buffer $(20 \mathrm{mmol} / \mathrm{L} \mathrm{HEPES}, 100 \mathrm{mmol} / \mathrm{L} \mathrm{NaCl}$, and $5 \mathrm{mmol} / \mathrm{L}$ $\mathrm{MgCl}_{2}, \mathrm{pH}$ 7.4), and the protein concentration was determined using the Bradford method ${ }^{[20]}$. The exchange of $\left[{ }^{35} \mathrm{~S}\right]-$ GTP $\gamma \mathrm{S}$ was measured using a scintillation proximity assay, as previously described ${ }^{[21]}$. For each assay point, $5 \mu \mathrm{g}$ membrane was incubated in $100 \mu \mathrm{L}$ reaction buffer for $3 \mathrm{~h}$ at $30{ }^{\circ} \mathrm{C}$ with $100 \mu \mathrm{g}$ FlashBlue GPCR beads, $10 \mu \mathrm{mol} / \mathrm{L}$ GDP, $10 \mu \mathrm{g} / \mathrm{mL}$ saponin, $0.2 \mathrm{nmol} / \mathrm{L}\left[{ }^{35} \mathrm{~S}\right]-\mathrm{GTP} \gamma \mathrm{S}$, and the indicated concentration of compounds. For non-specific basal binding measurement, $2 \mu \mathrm{mol} / \mathrm{L}$ GTP $\gamma \mathrm{S}$ was added. Membrane-bound $\left[{ }^{35} \mathrm{~S}\right]-\mathrm{GTP} \gamma \mathrm{S}$ was measured with a Microbeta scintillation counter (PerkinElmer, Waltham, MA, USA).

HTS campaign The compound library used for the screening of DOR modulators was comprised of 48000 different compounds. A 10 compound pool/well mix was applied to the primary screening in the antagonistic mode, with an average final concentration of $4.4 \mu \mathrm{mol} / \mathrm{L}$ for each compound. This matrix system maximized the advantage of HTS and allowed duplicate screening of each compound ${ }^{[22]}$. In each 96 -well plate, 8 wells were used as positive controls (100 nmol/L TIPP- $\psi$ in 1\% DMSO) and another set of 8 wells as negative controls ( $1 \% \mathrm{DMSO})$. The inhibition rate of 100 nmol/L TIPP- $\psi$ was normalized to $100 \%$, and that of the negative control was 0 . The inhibition rate of each compound was calculated with the following equation:

Inhibition $\%=\left(\right.$ Calcium peak value ${ }_{\text {compound }}-$ calcium peak value $\left._{1 \% \mathrm{DMSO}}\right) /\left(\right.$ calcium peak value $_{\mathrm{TIPP}-\psi}$-calcium peak value $1 \% \mathrm{DMSO}) \times 100 \%$. The samples showing more than $70 \%$ inhibition were considered "hits" in the primary screening.

Data analysis Data were analyzed with GraphPad Prism software (GraphPad, San Diego, CA, USA). Non-linear regression analyses were performed to generate dose-response curves and calculate $\mathrm{EC}_{50}$ or $\mathrm{IC}_{50}$ values. Linear regression was used to analyze data reproducibility. Two-tailed Student's $t$-test was applied to analyze differences. The Z' factor was calculated by the following equation:
$Z^{\prime}=1-\left(3 \mathrm{SD}_{+}+3 \mathrm{SD}_{-}\right) / \mid \mathrm{Ave}_{+}-$Ave $_{-} \mid$, where $\mathrm{SD}_{+}$is the standard deviation of the positive control, $\mathrm{SD}_{-}$is the standard deviation of the negative control, Ave $_{+}$is the mean value of the positive control, and Ave_ is the mean value of the negative control.

\section{Results}

G $\alpha 15 / 16$ can couple to various GPCR and mediate calcium response In the present study, we first tested whether promiscuous G-protein Ga15/16 could couple to different types of GPCR and mediate calcium response upon stimulation. Five Gai/o-coupled (DOR, CB1, CB2, CCR5, and CXCR4), 3 Gos-coupled ( $\alpha 2 \mathrm{bAR}, \beta 2 \mathrm{AR}$, and DRD5), and 1 Gaq-coupled ( $\alpha 1 \mathrm{aAR})$ receptors were coexpressed in CHO-K1 or HEK293 cells with Ga15/16, and calcium assay was carried out as described earlier. Representative kinetic and dose-response curves are shown in Figure 1, and the $\mathrm{EC}_{50}$ of various ligands are summarized in Table 1. For most of the Gai/o- and Gas-coupled receptors, agonist stimulation caused little or no change in the intracellular calcium concentration, and the calcium assay could not be used to measure the $\mathrm{EC}_{50}$ value of ligands (Figure 1; Table 1). When co-expressed with Ga15/16, all receptors produced a significant calcium-elevating effect after proper stimulation (Figure 1; Table 1). We also found that overexpression of Ga15/16 made little difference in the calcium response generated by Gaq-coupled receptor $\alpha 1 \mathrm{aAR}$ (Figure 1E,1F). One of the receptor $\alpha 2 \mathrm{bAR}$ mainly coupled to Gas, was also reported to induce calcium response by coupling to plasma membrane calcium channels ${ }^{[23]}$. Overexpression of Ga15/16 with $\alpha 2 \mathrm{bAR}$ increased the calcium assay's sensitivity, as indicated in the reduction of $\mathrm{EC}_{50}$ value of noradrenaline (Table 1). For all the receptors tested, the sensitivity of Ga15/16-mediated calcium assay was comparable with or sometimes more sensitive than the traditional cAMP or $\left[{ }^{35} \mathrm{~S}\right]-\mathrm{GTP} \gamma \mathrm{S}$ assays (Table 1). We also found cells stably transfected with DOR and Ga15/ 16 gave higher and longer-sustained calcium signals compared to transient transfected cells (supplement Figure 1S). This was likely due to the higher expression level of the receptor and Ga15/16 protein in stably transfected cells (supplement Figure 1S, 2S and Table 1S). For further characterization of this calcium assay, stable cell lines were used.

Agonist and antagonist mode of the calcium assay DOR was chosen as a model receptor to test the applicability of this calcium assay. DOR is a Gai/o-coupled receptor that plays important roles in various diseases, but lacks straightforward functional HTS assays. We tested a 

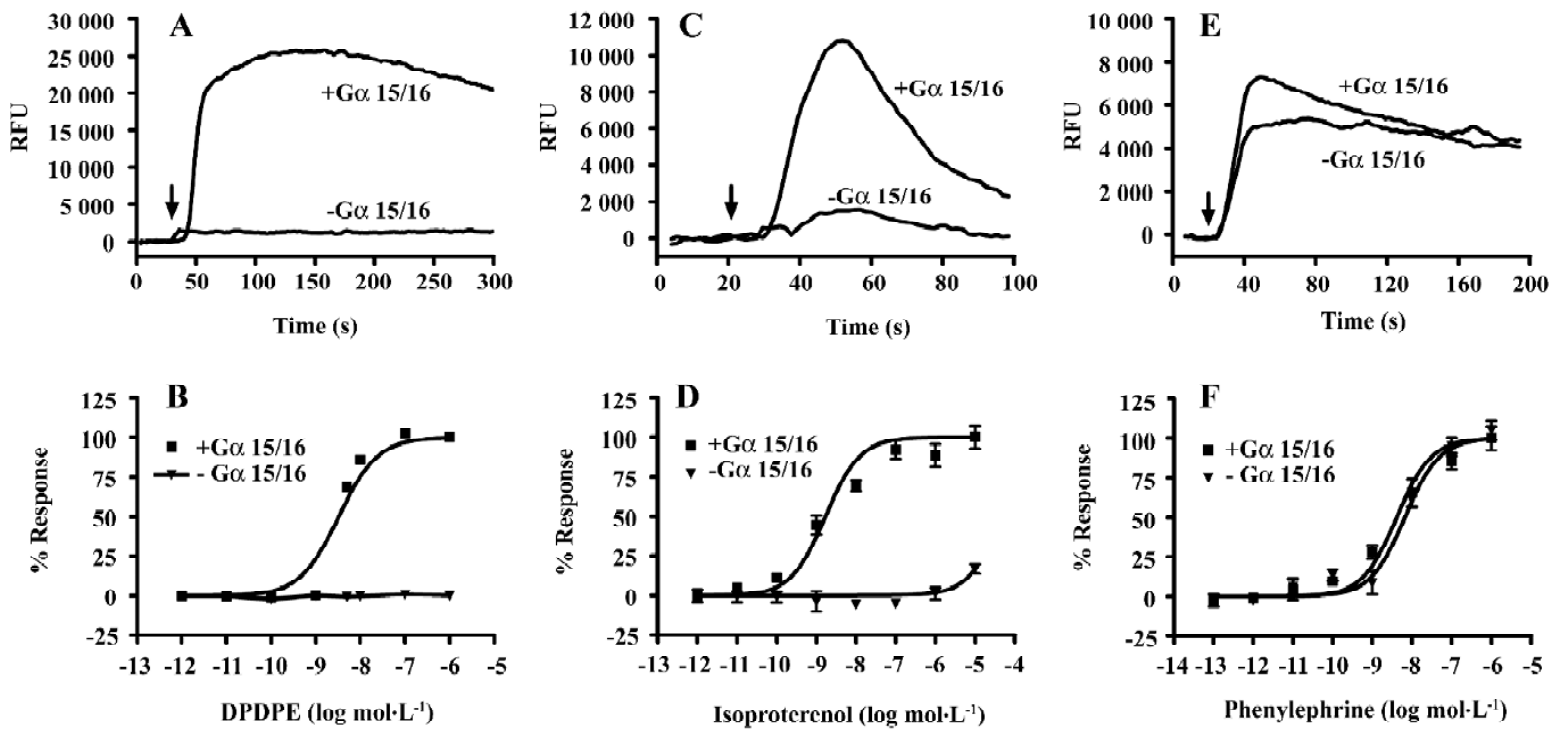

Figure 1. Kinetic and dose-response curves of calcium mobilization assay of representative GPCR. CHO or HEK293 cells were transfected with DOR (A,B), $\beta 2 \mathrm{AR}(\mathrm{C}, \mathrm{D})$, or $\alpha 1 \mathrm{aAR}(\mathrm{E}, \mathrm{F})$ together with G $\alpha 15 / 16$ or control plasmids. Proper ligands (5 nmol/L DPDPE for DOR, 10 $\mathrm{nmol} / \mathrm{L}$ isoproterenol for $\beta 2 \mathrm{AR}$, and $10 \mathrm{nmol} / \mathrm{L}$ phenylephrine for $\alpha 1 \mathrm{aAR}$ ) were added at the time points indicated by arrows, and representative kinetic curves of calcium response are presented (A,B,C). B, D, and F represent dose-response curves of proper ligands on their corresponding receptors. $n \geq 3$. Data are mean \pm SEM. RFU: relative fluorescent unit.

Table 1. Comparison of $\mathrm{EC}_{50}$ values of various ligands obtained by calcium assay and previously reported methods.

\begin{tabular}{|c|c|c|c|c|c|}
\hline \multirow[t]{2}{*}{ Receptor } & \multirow[t]{2}{*}{ G-protein } & \multirow[t]{2}{*}{ Agonist tested } & \multicolumn{2}{|c|}{$\mathrm{EC}_{50} / \mathrm{calcium}$ assay $(95 \% \mathrm{CI}, \mathrm{nmol} / \mathrm{L})$} & \multirow[t]{2}{*}{ Reported $\mathrm{EC}_{50}(\mathrm{nmol} / \mathrm{L}) /$ Functional assay used } \\
\hline & & & $-\mathrm{G} \alpha 15 / 16$ & $+\mathrm{G} \alpha 15 / 16$ & \\
\hline CB1 & Gai/o & CP55940 & UD & $2.8(2.2-3.5)$ & $2.6 \pm 1.0 / \mathrm{cAMP}$ assay ${ }^{[33]}$ \\
\hline $\mathrm{CB} 2$ & $\mathrm{G} \alpha \mathrm{i} / \mathrm{o}$ & CP55940 & UD & $8.7(5.7-13.1)$ & $2.9 \pm 1.4 / \mathrm{cAMP}$ assay $^{[33]}$ \\
\hline CCR5 & Gai/o & RANTES & UD & $3.8(3.3-4.5)$ & $\sim 1 /$ IP release assay ${ }^{[34]}$ \\
\hline CXCR4 & $\mathrm{G} \alpha \mathrm{i} / \mathrm{o}$ & SDF-1 & UD & $22.1(19.7-24.8)$ & $\sim 10 /\left[{ }^{35} \mathrm{~S}\right]-\mathrm{GTP} \gamma \mathrm{S}$ binding assay ${ }^{[35]}$ \\
\hline DOR & $\mathrm{G} \alpha \mathrm{i} / \mathrm{o}$ & DPDPE & UD & $3.3(2.4-4.4)$ & $\sim 4.6 / \mathrm{cAMP}$ assay $^{[36]}$ \\
\hline$\alpha 2 \mathrm{bAR}$ & Gos & Noradrenaline & $33.5(18.0-62.7)$ & $7.0 \quad(4.2-11.6)$ & $35.6 \pm 16.9 /$ calcium assay $^{[37]}$ \\
\hline DRD5 & Gos & Dopamine & UD & $23.8(12.5-45.4)$ & $364 \pm 91 / \mathrm{cAMP}$ assay $^{[38]}$ \\
\hline$\beta 2 \mathrm{AR}$ & Gas & Isoproterenol & UD & $1.7(1.0-2.7)$ & $2.4 \pm 0.2 / \mathrm{AC}$ activity assay ${ }^{[39]}$ \\
\hline$\alpha 1 \mathrm{aAR}$ & Gaq & Phenylephrine & $6.6(4.5-9.8)$ & $4.1(2.6-6.5)$ & $530 \pm 60 /\left[{ }^{3} \mathrm{H}\right]-\mathrm{IP} 1$ accumulation assay ${ }^{[40]}$ \\
\hline
\end{tabular}

AC, adenylyl cyclase; CI, confidence interval; IP, inositol phosphate; IP1, inositol monophosphate; UD, undetectable.

group of known DOR ligands (including 3 agonists: DPDPE, deltorphin II, and DADLE, and 2 antagonists: TIPP- $\psi$ and naltrindole) on cells that stably express DOR and Go15/16 with 2 different setups. In the antagonist testing mode (Figure 2A), test compounds were pre-incubated with the cells for $15 \mathrm{~min}$; then calcium assay was initiated by the addition of agonist DPDPE. In this setup, antagonists showed blocking effects as anticipated, and agonists also blocked the DPDPEinduced calcium response due to receptor desensitization during the pre-incubation period ${ }^{[24,25]}$. In the agonist-testing mode (Figure 2A), calcium assay was initiated by the direct addition of test compounds. All agonists showed a robust calcium-elevating effect, and antagonists did not cause any changes. So in the later HTS campaign, all compounds were tested in the antagonist mode in the primary screening to reveal any compounds that might block (antagonist) or desensitize (agonist) the receptor. The agonist mode was used in the secondary screening to distin- 


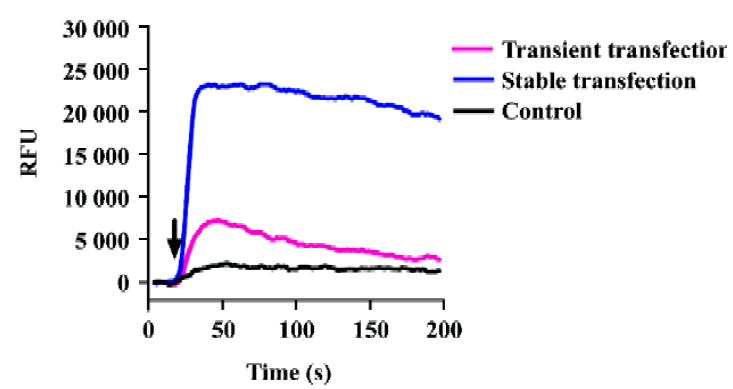

Figure 1S. Calcium signals in cells transiently or stably transfected with DOR and G $\alpha 15 / 16$. Compared to the weak and transient calcium signal in transient transfected cells, the signal of stable cell line was much higher and sustained longer. Sham transfected CHO cells were used as control.
A

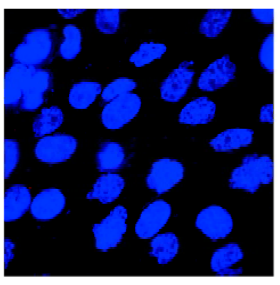

C

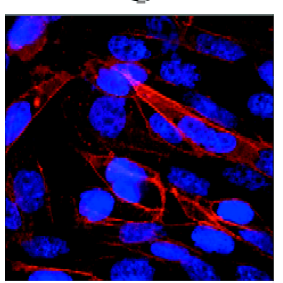

B

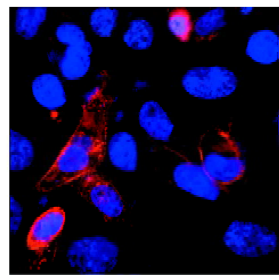

D

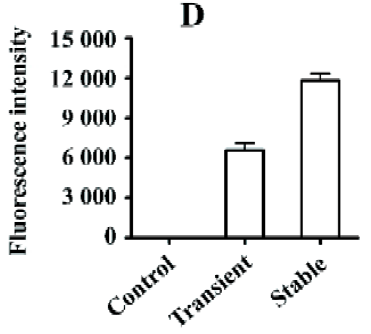

Figure 2S. Receptor expression level in cells transiently or stable transfected with DOR and Ga15/16. Fluorescent conjugated anti-HA antibody was used to detect HA-tagged DOR. (A), (B) and (C) are representative images of sham transfected, transient transfected and stably transfected CHO cells. (D) The statistical analysis of whole cell fluorescent intensity by ArrayScan ${ }^{\circledR}$ 4.0 HCS Reader (Cellomics, PA). More than 3000 cells from 10 randomly selected fields were used for the statistical analysis.

guish agonists from antagonists.

The $\mathrm{EC}_{50}$ values of known agonists were generated with the agonist mode of the calcium assay and the $\mathrm{IC}_{50}$ of known antagonists with the antagonist mode. These values were compared with those obtained with the traditional $\left[{ }^{35} \mathrm{~S}\right]-\mathrm{GTP} \gamma \mathrm{S}$ binding assay (Table 2), and both assays showed similar sensitivity.

Optimization and performance of the HTS assay Various experimental conditions were tested to optimize the assay for HTS. We found that cell density did not affect the $\mathrm{EC}_{50}$ value of the agonist DPDPE, but the signal to back-
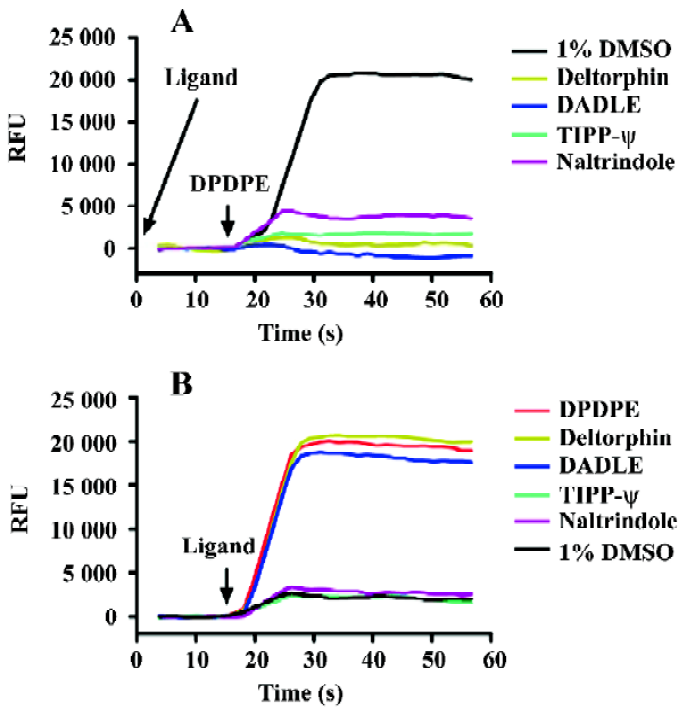

Figure 2. Antagonist and agonist mode of calcium mobilization assay demonstrated on DOR. (A) in the antagonist mode, CHO-K1 cells stably expressing DOR and G $15 / 16$ were loaded with Fluo-4 AM and pre-incubated with various ligands (including 2 agonists: deltorphin and DADLE, and 2 antagonists: TIPP- $\psi$ and naltrindole, all at $100 \mathrm{nmol} / \mathrm{L}, 1 \%$ DMSO as control) for $15 \mathrm{~min}$. Then the DOR agonist DPDPE $(10 \mathrm{nmol} / \mathrm{L})$ was added, and the kinetic curves of calcium response were recorded. Due to receptor desensitization, pre-incubated agonists also showed blocking effects. (B) in the agonist mode, the cells were loaded with dye, and calcium assay was carried out by the direct addition of ligands. Agonists displayed a calcium-elevating effect, and antagonists did not induce any response.

ground $(\mathrm{S} / \mathrm{B})$ ratio of the calcium response reached a plateau at a cell density of $30000 /$ well. The solvent used for compounds, DMSO, did not affect the S/B ratio at concentrations up to $1 \%$, and hardly interfered with the dose-response curves at concentrations up to $2 \%$ (Figure 3C,3D). The final assay conditions for HTS were determined as follows: the cell density was $30000 /$ well, the final concentration of DMSO was $1 \%$, and the DPDPE concentration was 10 $\mathrm{nmol} / \mathrm{L}$ (approximately $\mathrm{EC}_{80}$ ).

The $Z^{\prime}$ value is a metric used to assess the robustness of an assay for screening and is the normalized 3 standard deviation window between the negative controls and positive controls $^{[26]}$. As shown in Figure 4A, the $Z^{\prime}$ value for the assay was 0.64 , and the $\mathrm{S} / \mathrm{B}$ ratio was 18.86 , indicating that the system was adequately optimized for HTS. Furthermore, to investigate reproducibility between duplicate plates, the corresponding wells from 2 different 96-well plates were treated with the same concentration of TIPP- $\psi$ and then 10 nmol/L DPDPE. The data from the corresponding wells of different plates were investigated with liner regression analy$\operatorname{sis}^{[27]}$. The correlation coefficient was 0.95 , showing a high 


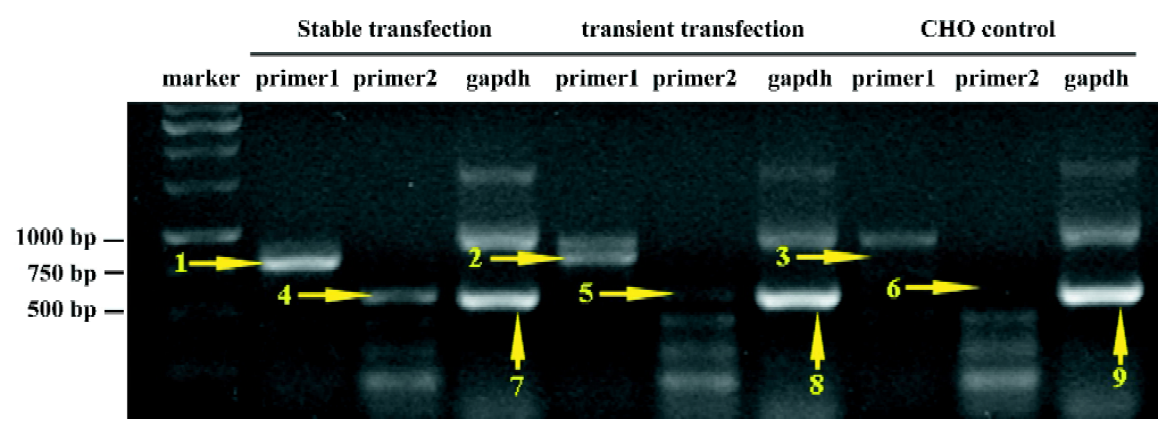

Figure 3S. RT-PCR results of cells transiently or stable transfected with DOR and Ga15/16. RT-PCR was applied to detect the mRNA level of Ga15/16. Arrow 1 and 2 indicated the expected products from primer pair 1. Arrow 4 and 5 indicated the expected products from primer pair

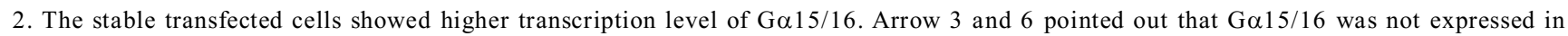
control cells. The transcription levels of GAPDH were similar in all cells (arrow 7, 8 and 9). Sequences of primer pairs were listed in Table 1S.

Table 1S. List of primers used for RT-PCR.

\begin{tabular}{|c|c|c|c|}
\hline Primer & Sense & Antisense & Product length \\
\hline Primer pair $1 \mathrm{G} \alpha 15 / 16$ & 5'-GGTGCCTGACGGAGGATGAG-3' & 5'-TGAGAAAGAGGATGACGGAT-3' & $793 \mathrm{bp}$ \\
\hline Primer pair $2 \mathrm{G} \alpha 15 / 16$ & 5'-CTACTATGAGCGTCGGCGGG-3' & 5'-GGCTGAAGAGGCGTCGGGAT-3' & $588 \mathrm{bp}$ \\
\hline GAPDH & 5'-ATCTTCTTGTGCAGTGCCAGCC-3' & 5'-GGTCATGAGCCCTTCCACAATG-3' & $560 \mathrm{bp}$ \\
\hline
\end{tabular}

Table 2. Comparison of $\mathrm{EC}_{50}$ or $\mathrm{IC}_{50}$ values of known DOR ligands generated with $\mathrm{G} \alpha 15 / 16$-mediated calcium assay and traditional $\left.{ }^{35} \mathrm{~S}\right]-\mathrm{GTP} \gamma \mathrm{S}$ binding assay.

\begin{tabular}{|c|c|c|c|c|c|}
\hline \multirow[t]{2}{*}{ Ligands tested } & \multirow[t]{2}{*}{ Nature of ligand } & \multicolumn{2}{|c|}{ Calcium assay } & \multicolumn{2}{|c|}{$\left[{ }^{35} \mathrm{~S}\right]-\mathrm{GTP} \gamma \mathrm{S}$ binding assay } \\
\hline & & $\begin{array}{c}\mathrm{EC}_{50}(\mathrm{nmol} / \mathrm{L} \\
95 \% \mathrm{CI})\end{array}$ & $\begin{array}{l}\mathrm{IC}_{50}(\mathrm{nmol} / \mathrm{L}, 95 \% \mathrm{CI}, \\
\mathrm{DPDPE}=10 \mathrm{nmol} / \mathrm{L})\end{array}$ & $\begin{array}{c}\mathrm{EC}_{50}(\mathrm{nmol} / \mathrm{L} \\
95 \% \mathrm{CI})\end{array}$ & $\begin{array}{r}\mathrm{IC}_{50}(\mathrm{nmol} / \mathrm{L}, 95 \% \mathrm{CI}, \\
\mathrm{DPDPE}=10 \mathrm{nmol} / \mathrm{L})\end{array}$ \\
\hline DPDPE & Agonist & $4.0(2.5-6.7)$ & NA & $1.3(0.4-3.7)$ & NA \\
\hline$\left[\mathrm{D}-\mathrm{Ala}^{2}\right]$-deltorphin II & Agonist & $2.2(1.3-3.5)$ & NA & $7.2(4.0-12.9)$ & NA \\
\hline DADLE & Agonist & $2.1(1.1-4.2)$ & NA & $4.2(2.4-7.2)$ & NA \\
\hline ТIPP- $\psi$ & Antagonist & NA & $1.0(0.5-2.4)$ & NA & $4.7(2.3-9.6)$ \\
\hline Naltrindole & Antagonist & NA & $2.7(1.2-5.7)$ & NA & $4.6(1.0-21.4)$ \\
\hline
\end{tabular}

NA: not applicable.

degree of reproducibility between duplicate sample plates.

Results of HTS campaign Of the 48000 compounds initially screened, 273 hits (0.57\%) showing greater than $70 \%$ inhibition on $10 \mathrm{nmol} / \mathrm{L}$ DPDPE-induced calcium response were discovered (Figure 5A). Secondary screening (single compound per well) was done to further confirm the hits (Figure 5B). Finally, 8 compounds displaying consistent inhibitory effects from the secondary screening were picked out and tested on other GPCR (CCR5 and CXCR4; data not shown) for receptor specificity. Four compounds with rela- tively high receptor specificity for DOR were further tested to distinguish their agonist or antagonist nature (Figure $5 \mathrm{C}$, 5D). Three of the compounds (TZ-02, TZ-03, and TZ-04) showed moderate to weak agonist properties, as they were found to induce calcium response in DOR- and G $\alpha 15 / 16$ coexpressing cells. One compound TZ-01 showed pure antagonist property. The activities of these compounds were further validated with $\left[{ }^{35} \mathrm{~S}\right]-\mathrm{GTP} \gamma \mathrm{S}$ binding assay (Table 3). Compounds TZ-02 and TZ-04 were proven to be agonists, and compound TZ-01 was an antagonist. Compound TZ-03 

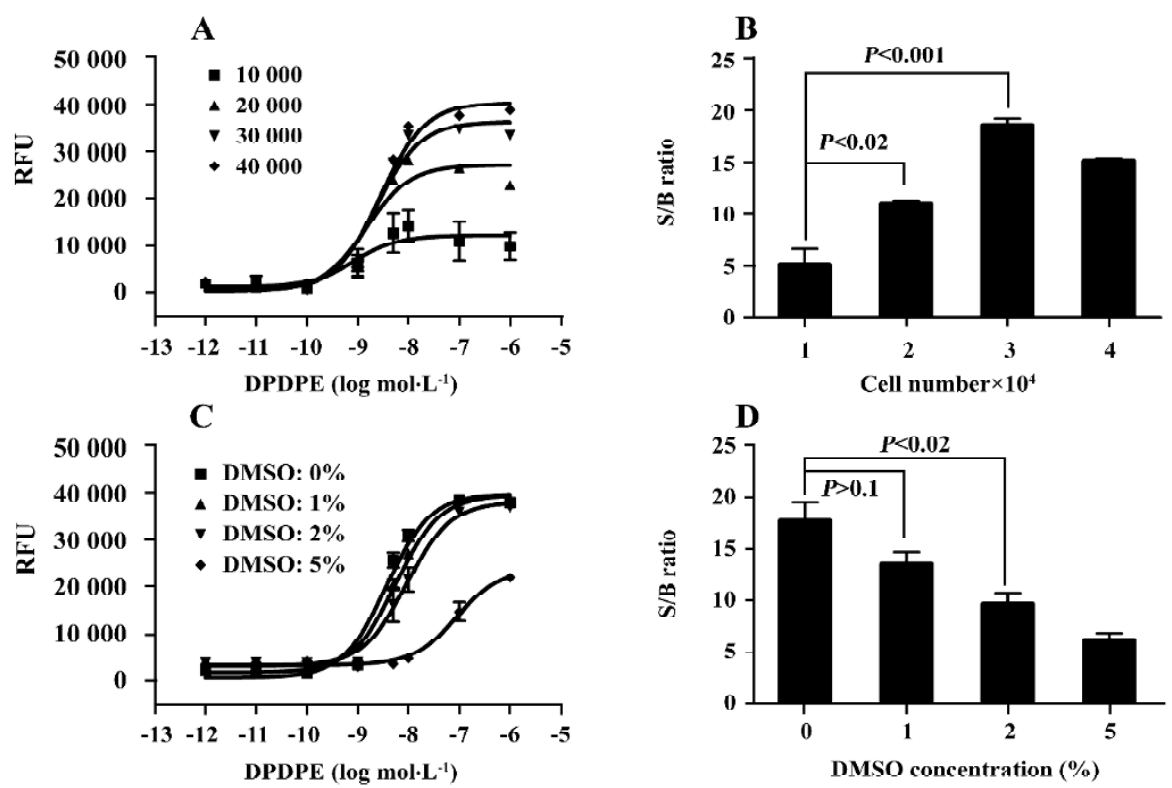

Figure 3. HTS assay optimization. (A) with different cell densities, the $\mathrm{EC}_{50}$ values of DOR agonist DPDPE obtained from the calcium assay were almost the same $(0.8-2.8 \mathrm{nmol} / \mathrm{L})$, but the $\mathrm{S} / \mathrm{B}$ ratio was significantly higher with increased cell density (B). (C,D) at concentrations up to $2 \%$, DMSO did not affect dose-response curves; and at concentrations up to $1 \%$, did not affect the $\mathrm{S} / \mathrm{B}$ ratio. $n \geq 3$. Data presented are mean \pm SEM.

$\mathbf{A}$

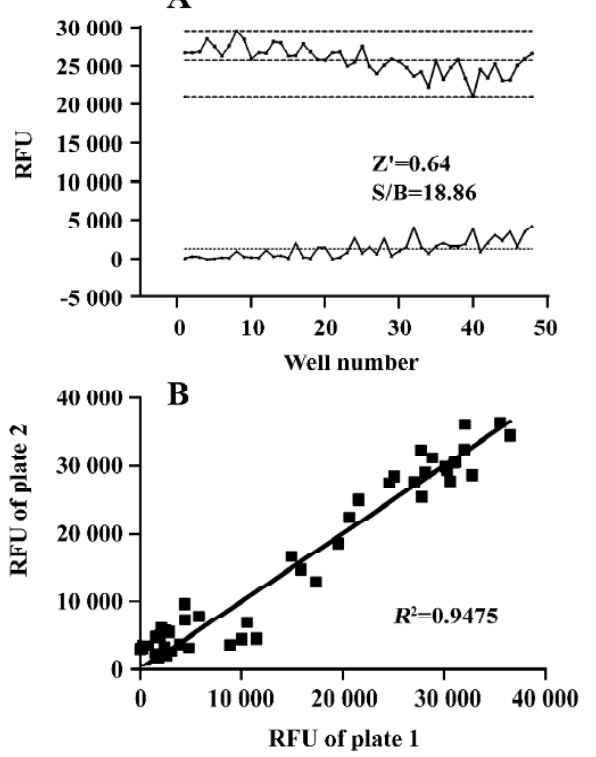

Figure 4. Assay performance. (A) Z' factor determination. At the optimized conditions, 48 replicates of positive and negative signals were studied. Dashed lines indicate mean $\pm 3 \mathrm{SD}$ of 48 data points. $Z^{\prime}$ value for the assay was 0.64 , and the $\mathrm{S} / \mathrm{B}$ ratio was 18.86 , indicating that the system was adequately optimized for HTS. (B) reproducibility. Corresponding wells from 2 different 96-well plates were stimulated with same concentration of DPDPE. Reproducibility of data from duplicate plates was investigated with a linear regression analysis. Correlation coefficient was 0.95 , showing a high degree of reproducibility between duplicate sample plates. was a partial agonist/antagonist. Its weak agonist activity can only be detected in the sensitive calcium assay, but not in the $\left[{ }^{35} \mathrm{~S}\right]-\mathrm{GTP} \gamma \mathrm{S}$ binding assay due to a limited assay window. The strong antagonist property of TZ-03 was confirmed by both assays.

\section{Discussion}

Considerable effort has been directed towards the development of HTS platforms for the GPCR because these cell surface receptors represent important drug targets ${ }^{[28]}$. Detection methods have moved a long way from membranebased radioligand binding assay towards cell-based functional assays. Most functional assays rely on the detection of the changes of different downstream effectors induced by receptor activation. Due to the versatility of GPCRinduced intracellular changes, it is sometimes difficult to handle and compare results from different assay systems. Meanwhile, with the cloning of more and more orphan GPCR, their implications as potential drug targets require vigorous validation. Little knowledge exists today regarding their native ligands and coupling mechanisms, and this makes HTS assay development extremely difficult. Thus, a universal HTS approach for GPCR ligand screening would be highly valuable.

Calcium mobilization assay with fluorescent dyes is a highly sensitive and easy-to-handle method that has been 

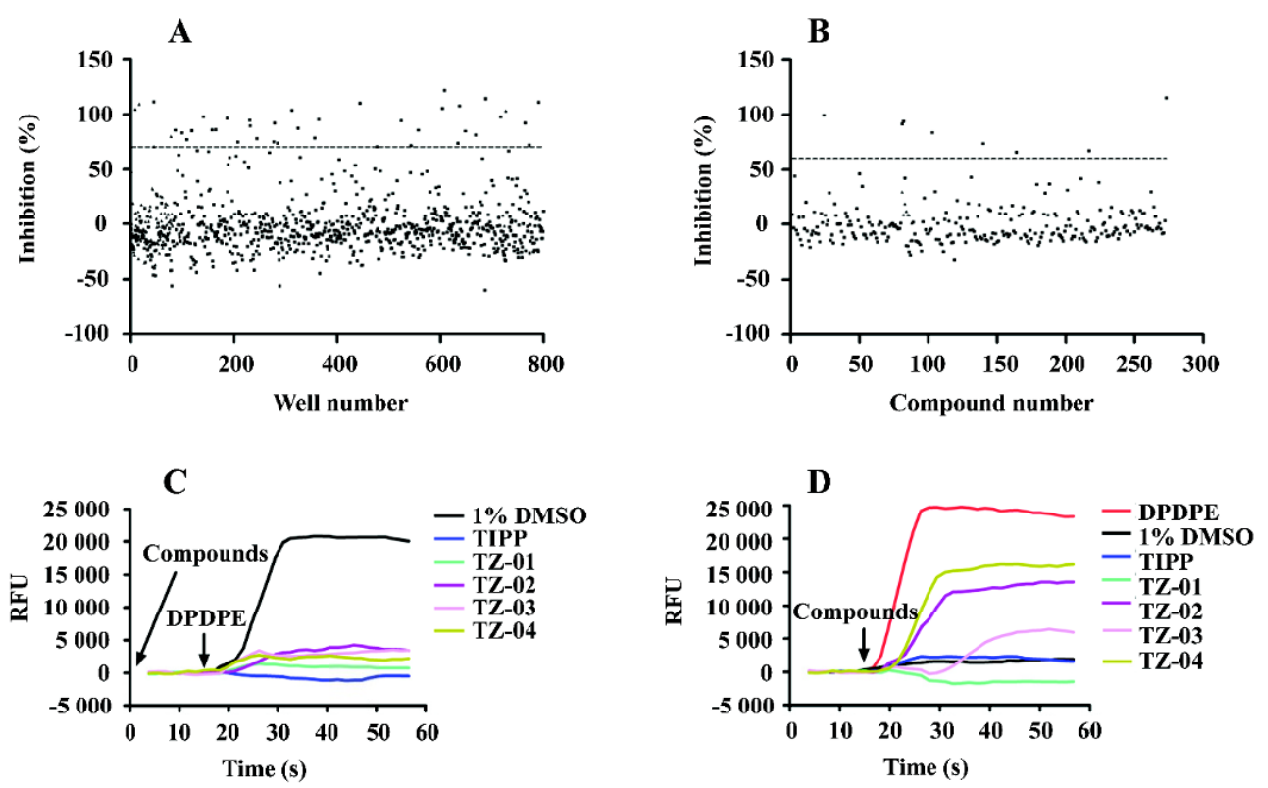

Figure 5. HTS of 48000 compounds. (A) representative result of primary screening of 800 wells. (B) compounds with $\geq 70 \%$ inhibition rate in the primary screening were further tested in a single compound/well setup. Four compounds with novel structure from secondary screening were picked out and further tested in a triplet setup to identify their agonist or antagonist nature. (C) in the antagonist testing mode, all compounds showed a consistent blocking effect of DPDPE. (D) in the agonist testing mode, 3 compounds (TZ-02, TZ-03, and TZ-04) showed moderate to weak agonist activity, and 1 compound TZ-01 showed pure antagonist property.

Table 3. Validation of newly-discovered DOR modulators with $\left[{ }^{35} \mathrm{~S}\right]-\mathrm{GTP} \gamma \mathrm{S}$ binding assay.

\begin{tabular}{|c|c|c|c|c|c|}
\hline \multirow[t]{2}{*}{ Compounds } & \multirow[t]{2}{*}{ Nature of compounds } & \multicolumn{2}{|c|}{ Calcium assay } & \multicolumn{2}{|c|}{$\left[{ }^{35} \mathrm{~S}\right]-\mathrm{GTP} \gamma \mathrm{S}$ binding assay } \\
\hline & & $\begin{array}{r}\mathrm{EC}_{50}(95 \% \\
\mathrm{CI}, \mu \mathrm{mol} / \mathrm{L})\end{array}$ & $\begin{array}{l}\mathrm{IC}_{50}(95 \% \mathrm{CI}, \mu \mathrm{mol} / \mathrm{L}) \\
(\mathrm{DPDPE}=10 \mathrm{nmol} / \mathrm{L})\end{array}$ & $\begin{array}{c}\mathrm{EC}_{50}(95 \% \\
\mathrm{CI}, \mu \mathrm{mol} / \mathrm{L})\end{array}$ & $\begin{array}{c}\mathrm{IC}_{50}(95 \% \mathrm{CI}, \mu \mathrm{mol} / \mathrm{L}) \\
(\mathrm{DPDPE}=10 \mathrm{nmol} / \mathrm{L})\end{array}$ \\
\hline TZ-0 1 & Antagonist & NA & $46.6(16.4-132.2)$ & NA & $40.0(18.9-84.7)$ \\
\hline TZ-02 & Agonist & $3.5(2.2-5.6)$ & NA & $1.8(1.1-3.1)$ & NA \\
\hline TZ-03 & Partial agonist /antagonist & $0.8(0.3-2.2)$ & $0.015(0.009-0.024)$ & UD & $0.0002(0.00003-0.0016)$ \\
\hline TZ-04 & Agonist & $0.6(0.4-1.1)$ & NA & $1.1(0.6-2.0)$ & NA \\
\hline
\end{tabular}

widely applied to study ligand or voltage-gated ion channels and GPCR coupled to the Gaq-protein ${ }^{[29]}$. It is critical to provide the receptors with a universal and efficient calcium signal transducer if this method is to be used to search modulators for various GPCR. It has been reported that the Gaqprotein with the last 5 amino acids exchanged with Gos- or Gai-proteins (designated as Gqs5 and Gqi5 $5^{[30]}$ ) can couple to

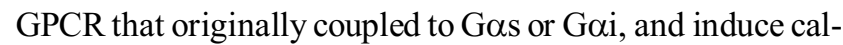
cium mobilization upon stimulation. In the present study, we tested the versatility of another Gaq subfamily protein Ga15/16.

A panel of 9 GPCR that originally coupled to different types of G-proteins was studied. These included $5 \mathrm{G \alpha i} / \mathrm{o}-$ coupled(DOR, CB1, CB2, CCR5, and CXCR4), 3 Gas-coupled
( $\alpha 2 \mathrm{bAR}, \beta 2 \mathrm{AR}$, and DRD5) and $1 \mathrm{G} \alpha \mathrm{q}$-coupled ( $\alpha 1 \mathrm{aAR})$ receptors. With the exception of $\alpha$ laAR, which originally coupled to Gaq, and $\alpha 2 \mathrm{bAR}$, which was reported to modulate plasma membrane calcium channels ${ }^{[23]}$, other receptors could not elicit measurable calcium responses upon stimulation when they were expressed alone in CHO-K1 or HEK293 cells. After co-expression with Ga15/16, all receptors were coupled to the calcium mobilization pathway, and the $\mathrm{EC}_{50}$ values of the ligands measured with this assay were in close agreement or more sensitive than other reported methods.

We further characterize the Ga15/16-mediated calcium assay on DOR. DOR has been heavily studied in the past for its roles in pain and drug addiction ${ }^{[31,32]}$. It has been a focus of attention again recently due to its involvement in neurode- 
generative and autoimmune diseases ${ }^{[16,18]}$. Traditional HTS methods for searching DOR ligands include radioligand binding, $\left[{ }^{35} \mathrm{~S}\right]-\mathrm{GTP} \gamma \mathrm{S}$ binding, and cAMP assay. Both $\left[{ }^{35} \mathrm{~S}\right]-$ GTP $\gamma \mathrm{S}$ binding and cAMP assay can only be used to search agonists or antagonists in a single HTS run. Radioligand binding is the only way to find both agonists and antagonists simultaneously, even though the separation of agonists from antagonists needs a secondary functional assay. We found the calcium assay to be very efficient in detecting both agonists and antagonists if the testing compounds were pre-incubated with the cells before the addition of agonist DPDPE. In this experimental setup, agonists can also block the DPDPE-induced calcium response due to receptor desensitization during the pre-incubation period. Thus, any compounds that reduce the DPDPE-elicited calcium signal could be a potential DOR modulator. Later on, the agonist or antagonist nature of the compound can be simply distinguished by direct application of the compound to the cells to see whether it can induce calcium change or not.

Various assay parameters were optimized to improve the assay window and stability. The $Z^{\prime}$ factor is a useful tool for evaluating bioassay qualities ${ }^{[26]}$. In general, a $Z^{\prime}$ value above 0.5 suggests that an assay is robust enough for HTS. The calcium mobilization system described herein displayed a $Z^{\prime}$ value of 0.64 , which indicated that the assay was of a highquality nature. This assay was applied to a large-scale screening of a compound library consisting of 48000 synthetic compounds. Four compounds with novel structures and relatively high receptor specificity were sorted out and further validated with a traditional $\left[{ }^{35} \mathrm{~S}\right]-\mathrm{GTP} \gamma \mathrm{S}$ binding assay. Two of these compounds were found to be agonists and 1 to be antagonist. The other was a partial agonist/antagonist that displayed very weak agonist, but strong antagonist activity.

In summary, a universal, cell-based, G $\alpha 15 / 16-$ mediated calcium assay was developed and validated for the identification of compounds that modulate DOR activity. Its application may be expanded to other GPCR and even orphan receptors.

\section{References}

1 George SR, O'Dowd BF, Lee SP. G-protein-coupled receptor oligomerization and its potential for drug discovery. Nat Rev Drug Discov 2002; 1: 808-20.

2 Marchese A, George SR, Kolakowski LF Jr, Lynch KR,O'Dowd BF. Novel GPCRs and their endogenous ligands: expanding the boundaries of physiology and pharmacology. Trends Pharmacol Sci 1999; 20: 370-5.

3 Drews J. Drug discovery: a historical perspective. Science 2000; 287: $1960-4$
4 Ma P, Zemmel R. Value of novelty? Nat Rev Drug Discov 2002; 1: $571-2$.

5 Schoneberg T, Hofreiter M, Schulz A,Rompler H. Learning from the past: evolution of GPCR functions. Trends Pharmacol Sci 2007; 28: 117-21.

6 Pierce KL, Premont RT,Lefkowitz RJ. Seven-transmembrane receptors. Nat Rev Mol Cell Biol 2002; 3: 639-50.

7 Hamm HE. The many faces of $\mathrm{G}$ protein signaling. J Biol Chem 1998; 273: 669-72.

8 Bartfai TJLB, Bockaert J, Bond RA, Bouvier M, Christopoulos A, et al. Twenty questions. Nat Rev Drug Discov 2004; 3: 577626.

9 Umemori $\mathrm{H}$, Inoue $\mathrm{T}$, Kume $\mathrm{S}$, Sekiyama $\mathrm{N}$, Nagao $\mathrm{M}$, Itoh $\mathrm{H}$, et al. Activation of the $\mathrm{G}$ protein $\mathrm{Gq} / 11$ through tyrosine phosphorylation of the alpha subunit. Science 1997; 276: 1878-81.

10 Berridge MJ. Inositol trisphosphate and calcium signalling. Nature 1993; 361: 315-25.

11 Yuan J, Rey O,Rozengurt E. Activation of protein kinase D3 by signaling through Rac and the alpha subunits of the heterotrimeric G proteins G12 and G13. Cell Signal 2006; 18: 1051-62.

12 Wise A, Jupe SC,Rees S. The identification of ligands at orphan G-protein coupled receptors. Annu Rev Pharmacol Toxicol 2004; 44: 43-66.

13 Cabrera-Vera TM, Vanhauwe J, Thomas TO, Medkova M, Preininger A, Mazzoni MR,Hamm HE. Insights into G protein structure, function, and regulation. Endocr Rev 2003; 24: 76581 .

14 Coward P, Chan SD, Wada HG, Humphries GM, Conklin BR. Chimeric $\mathrm{G}$ proteins allow a high-throughput signaling assay of Gi-coupled receptors. Anal Biochem 1999; 270: 242-8.

$15 \mathrm{Gu}$ JL, Lu W, Xia C, Wu X, Liu M. Regulation of hematopoieticspecific G-protein Galpha15 and Galpha16 by protein kinase C. J Cell Biochem 2003; 88: 1101-11.

16 Shi Y, Feng Y, Kang J, Liu C, Li Z, Li D, et al. Critical regulation of CD4+ T cell survival and autoimmunity by beta-arrestin 1 . Nat Immunol 2007; 8: 817-24.

17 Raut A, Rao VR, Ratka A. Changes in opioid receptor proteins during mitochondrial impairment in differentiated SK-N-SH cells. Neurosci Lett 2007; 422: 187-92.

18 Ni Y, Zhao X, Bao G, Zou L, Teng L, Wang Z, et al. Activation of beta2-adrenergic receptor stimulates gamma-secretase activity and accelerates amyloid plaque formation. Nat Med 2006; 12: $1390-6$.

19 Hipkin RW, Friedman J, Clark RB, Eppler CM, Schonbrunn A. Agonist-induced desensitization, internalization, and phosphorylation of the sst2A somatostatin receptor. J Biol Chem 1997; 272: 13869-76.

20 Bradford MM. A rapid and sensitive method for the quantitation of microgram quantities of protein utilizing the principle of protein-dye binding. Anal Biochem 1976; 72: 248-54.

21 Gonsiorek W, Zavodny P, Hipkin RW. The study of CXCR3 and CCR7 pharmacology using $\left[{ }^{35} \mathrm{~S}\right] \mathrm{GTP}$ gammaS exchange assays in cell membranes and permeabilized peripheral blood lymphocytes. J Immunol Methods 2003; 273: 15-27.

22 Hann M, Hudson B, Lewell X, Lifely R, Miller L, Ramsden N. Strategic pooling of compounds for high-throughput screening. J Chem Inf Comput Sci 1999; 39: 897-902.

23 Davare MA, Avdonin V, Hall DD, Peden EM, Burette A, Weinberg 
$\mathrm{RJ}$, et al. A beta2 adrenergic receptor signaling complex assembled with the Ca2+ channel Cav1.2. Science 2001; 293: 98101 .

24 Borgland SL. Acute opioid receptor desensitization and tolerance: is there a link? Clin Exp Pharmacol Physiol 2001; 28: 147-54.

25 Law PY, Loh HH. Regulation of opioid receptor activities. J Pharmacol Exp Ther 1999; 289: 607-24.

26 Zhang JH, Chung TD, Oldenburg KR. A simple statistical parameter for use in evaluation and validation of high throughput screening assays. J Biomol Screen 1999; 4: 67-73.

27 Ghosh RN, DeBiasio R, Hudson CC, Ramer ER, Cowan CL, Oakley RH. Quantitative cell-based high-content screening for vasopressin receptor agonists using transfluor technology. J Biomol Screen 2005; 10: 476-84.

28 Liu AM, Ho MK, Wong CS, Chan JH, Pau AH, Wong YH. Galpha $(16 / \mathrm{z})$ chimeras efficiently link a wide range of $\mathrm{G}$ protein-coupled receptors to calcium mobilization. J Biomol Screen 2003; 8: 3949.

29 Takahashi A, Camacho P, Lechleiter JD, Herman B. Measurement of intracellular calcium. Physiol Rev 1999; 79: 1089-125.

30 An S, Bleu T, Zheng Y. Transduction of intracellular calcium signals through $\mathrm{G}$ protein-mediated activation of phospholipase $\mathrm{C}$ by recombinant sphingosine 1-phosphate receptors. Mol Pharmacol 1999; 55: 787-94.

31 Kest B, Lee CE, McLemore GL, Inturrisi CE. An antisense oligodeoxynucleotide to the delta opioid receptor (DOR-1) inhibits morphine tolerance and acute dependence in mice. Brain Res Bull 1996; 39: 185-8.

32 Quock RM, Burkey TH, Varga E, Hosohata Y, Hosohata K, Cowell $\mathrm{SM}$, et al. The delta-opioid receptor: molecular pharmacology, signal transduction, and the determination of drug efficacy. Pharmacol Rev 1999; 51: 503-32.

33 Ross RA, Brockie HC, Stevenson LA, Murphy VL, Templeton F,
Makriyannis A, et al. Agonist-inverse agonist characterization at CB1 and CB2 cannabinoid receptors of L759633, L759656, and AM630. Br J Pharmacol 1999; 126: 665-72.

34 Raport CJ, Gosling J, Schweickart VL, Gray PW, Charo IF. Molecular cloning and functional characterization of a novel human CC chemokine receptor (CCR5) for RANTES, MIP-1beta, and MIP-1alpha. J Biol Chem 1996; 271: 17161-6.

35 Fricker SP, Anastassov V, Cox J, Darkes MC, Grujic O, Idzan SR, et al. Characterization of the molecular pharmacology of AMD3100: a specific antagonist of the G-protein coupled chemokine receptor, CXCR4. Biochem Pharmacol 2006; 72: 588-96.

36 Cai YC, Ma L, Fan GH, Zhao J, Jiang LZ, Pei G. Activation of $N$ methyl- $D$-aspartate receptor attenuates acute responsiveness of delta-opioid receptors. Mol Pharmacol 1997; 51: 583-7.

37 Holmberg CI, Kukkonen JP, Bischoff A, Nasman J, Courtney MJ, Michel MC, et al. Alpha2B-adrenoceptors couple to $\mathrm{Ca}^{2+}$ increase in both endogenous and recombinant expression systems. Eur J Pharmacol 1998; 363: 65-74.

38 Demchyshyn LL, McConkey F, Niznik HB. Dopamine D5 receptor agonist high affinity and constitutive activity profile conferred by carboxyl-terminal tail sequence. J Biol Chem 2000; 275: 23446-55.

39 Cunliffe JM, Sunahara RK, Kennedy RT. Detection of G protein coupled receptor mediated adenylyl cyclase activity by capillary electrophoresis using fluorescently labeled ATP. Anal Chem 2007; 79: 7534-9.

40 Arias-Montano JA, Berger VA, Soria-Jasso LE, Young JM. Characterisation of alpha1B-adrenoceptors linked to inositol phosphate formation and calcium mobilisation in human astrocytoma U373 MG cells. Naunyn Schmiedebergs Arch Pharmacol 1999; 360: 533-9. 